\title{
Detection of the Genes for Staphylococcus aureus Enterotoxin By PCR
}

\author{
L. TKÁČIKOVÁ, *A. TESFAYE, I. MIKULA
}

Laboratory of Biomedical Microbiology and Immunology, *Department of Anatomy, University of Veterinary Medicine, Košice, Slovakia

Received May 23, 12003

Accepted November 29, 2003

\section{Abstract}

Tkáčiková L., A. Tesfaye, I. Mikula: Detection of the Genes for Staphylococcus aureus Enterotoxins by PCR. Acta Vet. Brno 2003, 72: 627-630.

The aim of this study was to determine the presence of genes for staphylococcal enterotoxins in group of 32 isolates of Staphylococcus aureus from 75 samples (sheep, cow and goat raw milk) collected from sub-clinically and clinically sick sheep, goats and cows raised in different agricultural farms in the Eastern region of Slovakia and also from 12 samples of sheep cheeses. Fifteen out of 32 isolates of $S$. aureus carried gene for enterotoxin C (SEC): 12 from sheep raw milk and one from each of goat and cow raw milk and sheep cheese, too. Fifteen out of 32 isolates carried gene for enterotoxin D (SED): 12 from sheep raw milk, two from cow raw milk and one from sheep cheese. Two out of 32 isolates carried genes for enterotoxin A (SEA) and B (SEB): one positive isolate for SEA from sheep raw milk and the other SEB from sheep cheese.

Cheese, cow, goat, raw milk, sheep

Staphylococcus aureus produces different extra-cellular protein toxins and virulence factors, which stipulate its pathogenity due to their enterotoxins. The enterotoxins pass from the digestive tract to the blood circulation and consecutively activate the nerve centre of the emetic reflex, causing nausea, vomiting, abdominal cramps and diarrhea, which can lead to dehydration and the collapse of the organism (Gouloumes et al. 1996).

There are several types of staphylococcal enterotoxins: SEA, SEB, $\mathrm{SEC}_{1}, \mathrm{SEC}_{2}, \mathrm{SEC}_{3}$, SED and SEE. It was found that some strains of Staphylococcus aureus produce more than one type of enterotoxins (Halpin-Dohnálek and Marth 1989). Therefore the presence of Staphylococcus aureus in the food can be potential risk for health, particularly, if the food is not stored at the prescribed temperature.

There are several procedures to detect staphylococcal enterotoxins. The production of enterotoxin needs long incubation time $(20 \mathrm{~h})$. Some factors, which affect the incubation period, are the $\mathrm{pH}$, the water activity and the used substrates (Sharma et al. 2000). Numerous methods are based on the evidence of the enterotoxins directly in the food (ELISA, reversal passive latex agglutination and others), with a possibility to detect nanogram amounts of enterotoxins in one gram or in one mili-liter of food (B urd ová et al. 1994; Gouloumes et al. 1996; Strachan et al. 1997). The advantage of these methods is that enterotoxins are detected even if the producer Staphylococcus aureus should not be identified by the classical bacteriological procedure, because it is usually devitalized by temperature.

DNA amplification methods (polymerase chain reaction, PCR) can show the presence of enterotoxigenic strains of Staphylococcus aureus before the expression of enterotoxins on the base of specific gene sequences and in this way detect the potential source of contamination. The advantage of the PCR methods is that it is able to detect genes which code the production of staphylococcal enterotoxins also from heat treatment of food, because the DNA remains unchanged (Tsen and Chen 1992; Holečková et al. 2000).

Address for correspondence:

Doc. MVDr. L. Tkáčiková, PhD.

Department of Microbiology and Immunology

University of Veterinary Medicine

Komenského 73,041 81 Košice, Slovakia hone: +42155633608

Fax: +421 556335641

http://www.vfu.cz/acta-vet/actavet.htm 
Sharma et al. (2000) published multiplex PCR for the detection of all staphylococcus enterotoxins. They used one universal and five specific primers in one reaction. The result showed that this type of one-step PCR is very useful for detection of different staphylococcal enterotoxin genes. The aim of this work was to detect enterotoxins in sets of Staphylococcus aureus, isolated from the cow, sheep and goat raw milk and also sheep cheese.

\section{Materials and Methods}

Bacterial strains

Samples of Staphylococcus aureus were isolated by standard bacteriological guideline (EN ISO 6888) from the cow, sheep and goat raw milk and sheep cheese and stored at $-20{ }^{\circ} \mathrm{C}$ in $50 \%$ (vol/vol) glycerol, $50 \%$ Brain heart infusion (BHI; Oxoid Ltd., England). Bacterial isolates were grown at $37^{\circ} \mathrm{C}$ in $\mathrm{BHI}$ broth before the extraction of the DNA.

\section{DNA isolation}

Sediment obtained after centrifugation $\left(3 \mathrm{~min}, 3500 \mathrm{x} \mathrm{g}\right.$ ) of $1.5 \mathrm{ml}$ of broth culture $\left(24 \mathrm{~h}, 37^{\circ} \mathrm{C}\right)$ was washed with $10010.5 \%$ Triton X-100 (Koch-Light Lab. Ltd., England). Sediment was resuspended in $10010.5 \%$ Triton $\mathrm{X}-100$. The isolates were incubated at $95^{\circ} \mathrm{C}$ for $10 \mathrm{~min}$ and centrifuged at $3500 \mathrm{x} \mathrm{g}$ for $5 \mathrm{~min}$. The supernatant was used as a source of DNA.

Oligonucleotide primers

Oligonucleotide primers were used for PCR reaction according to Sharma et al. (2000).

DNA amplification

PCR reaction was done according to Sharma et al. (2000).

Detection of amplified DNA

For detection, 101 of PCR reaction mixture was electrophoresed on a $2 \%$ w/v agarose gel (Gibco BRL, USA), diluted in 1xTAE buffer (Sambrook at al. 1989), stained with ethidium bromide (Amresco, USA) in concentration $0.1 \mu \mathrm{g} / \mathrm{ml}$ and viewed under ultraviolet light. The $100 \mathrm{bp}$ DNA Ladder (New England BioLabs, England) was used as a standard of molecular weight.

\section{Results}

We have examined 87 isolates of $S$. aureus collected from food samples: 53 from sheep raw milk, 21 from cow raw milk, one from goat raw milk and 12 from sheep cheese in which we detected each of the toxin gene product by multiplex PCR (Plate XV, Fig. 1).

The maximum number of staphylococcal isolates ( 75 isolates) was collected from two farms: No. 2 (54 isolates) and No. 3 (21 isolates). We detected a high number of enterotoxin-positive isolates from farm No. 2, where $24(47 \%)$ isolates of $S$. aureus from sheep raw milk and one (33.3\%) from sheep cheese were positive for SED, SEC and SEA enterotoxin genes (Table 1). On the other hand, three (14.3\%) isolates of S. aureus from cow raw milk samples at farm No. 3 were positive for SED and SEC enterotoxin genes only.

The maximum numbers of staphylococcal isolates were positive for SEC and SED genes. We found that 15 isolates of $S$. aureus $(17.2 \%)$ possess gene for enterotoxin SEC, 12 from sheep raw milk and one from each of the goat and cow raw milk and sheep cheese, respectively. The gene for enterotoxin D (SED) possesses the same amount of isolates $S$. aureus (17.2\%), 12 from sheep raw milk, 2 from cow raw milk and one from sheep cheese. The genes for SEC and SED were detected mainly in staphylococci isolated from the sheep milk samples.

The gene for enterotoxin B (SEB) was detected only in one isolate (1.1\%) of S. aureus from sheep cheese and the gene for enterotoxin A (SEA) was detected in one isolate $(1.1 \%)$ from sheep raw milk, too (Table 1 and 2). 
Table1

Detection of staphylococcal enterotoxin genes in S. aureus isolates from food samples collected from different farms in the Eastern region of Slovakia

\begin{tabular}{|c|c|c|c|c|c|}
\hline \multirow{3}{*}{$\begin{array}{l}\text { Type of food } \\
\text { sample }\end{array}$} & \multirow[t]{3}{*}{ Farm No. } & \multirow{3}{*}{$\begin{array}{l}\text { No. of } \\
\text { isolates } \\
\text { (n) }\end{array}$} & \multicolumn{3}{|c|}{ Enterotoxin gene } \\
\hline & & & \multicolumn{2}{|c|}{ No. of positive } & \multirow{2}{*}{ Type } \\
\hline & & & (n) & $\%$ & \\
\hline \multirow[t]{4}{*}{ Sheep raw milk } & 1 & 2 & 1 & 50 & SEC \\
\hline & 2 & 51 & 1 & 2 & SEA \\
\hline & & & 11 & 21.6 & SEC \\
\hline & & & 12 & 23.5 & SED \\
\hline \multirow[t]{2}{*}{ Cow raw milk } & 3 & 21 & 1 & 4.8 & SEC \\
\hline & & & 2 & 9.5 & SED \\
\hline Goat raw milk & 4 & 1 & 1 & 100 & SEC \\
\hline \multirow[t]{8}{*}{ Sheep cheese } & 2 & 3 & 1 & 33.3 & SEC \\
\hline & 5 & 2 & - & - & \\
\hline & 6 & 1 & - & - & \\
\hline & 7 & 2 & 1 & 50 & SEB \\
\hline & 8 & 1 & - & - & \\
\hline & 9 & 1 & - & - & \\
\hline & 10 & 1 & - & - & \\
\hline & 11 & 1 & 1 & 100 & SEC, SED \\
\hline Total & 11 & 87 & 32 & 36.8 & \\
\hline
\end{tabular}

Table 2

Prevalence of staphylococcal enterotoxin genes in S. aureus isolates from food samples

\begin{tabular}{|l|c|c|c|c|c|c|c|}
\hline \multirow{2}{*}{$\begin{array}{l}\text { Origin of } \\
\text { S.aureus }\end{array}$} & \multirow{2}{*}{$\begin{array}{c}\text { No. of } \\
\text { tested } \\
(\mathrm{n})\end{array}$} & \multicolumn{6}{|c|}{ No. of enterotoxin positive samples } \\
\cline { 2 - 8 } & & SEA & SEB & SEC & SED & SEE & $\%$ \\
\hline Sheep raw milk & 53 & 1 & 0 & 12 & 12 & 0 & 47.2 \\
\hline Goat raw milk & 1 & 0 & 0 & 1 & 0 & 0 & 100 \\
\hline Cow raw milk & 21 & 0 & 0 & 1 & 2 & 0 & 14.3 \\
\hline Sheep cheese & 12 & 0 & 1 & 1 & 1 & 0 & 25 \\
\hline Total (n) & 87 & 1 & 1 & 15 & 15 & 0 & 36.8 \\
\cline { 2 - 9 } & & $1.1 \%$ & $1.1 \%$ & $17.2 \%$ & $17.2 \%$ & 0 & \\
\hline
\end{tabular}

\section{Discussion}

Many authors use PCR for detecting staphylococcal enterotoxin genes (Tornadijo et al. 1996; Holečková et al. 2000). All of them found a high variability (75-80\%) in the presence of enterotoxin genes. Our experiments confirmed this fact as well (Table 1 and 2).

We detected the genes for four types of enterotoxin in our set of staphylococci. Three types of them (SEA, SEC and SED) were detected in bacteria isolated from samples of sheep raw milk; three types of enterotoxin genes (SEB, SEC and SED) were detected in bacteria isolated from samples of sheep cheese; one type of enterotoxin gene (SEC) was detected in bacteria isolated from samples of goat raw milk and two genes (SEC and SED) were detected in bacteria isolated from samples of cow raw milk. Majority of enterotoxin positive staphylococci $(93.8 \%)$ carry genes for enterotoxin SEC and SED. These isolates of $\mathrm{S}$. aureus were collected from sheep raw milk (Table 2). 
Some data published by other authors show that staphylococcal enterotoxin type $\mathrm{C}$ is the most frequent type in the cow and sheep milk (Tornadijo et al. 1996; Stephan et al. 1999).

In conclusion, we detected the presence of enterotoxin genes in S. aureus isolates using PCR. They were collected from the samples of cow, sheep and goat raw milk from subclinically and clinically sick animals from different agricultural farms in the Eastern region of Slovakia. Relatively high prevalence of enterotoxin positive strains, 29 out of 75 isolates $(38.6 \%)$, was probably in direct correlation to the health status of the mammary gland of these animals. Relatively high prevalence of enterotoxigenic isolates from the sheep raw milk in farm No. 2, 24 out of 51 isolates (47\%), may probably influence the prevalence of enterotoxigenic $S$. aureus in other types of sheep food products, e.g. sheep cheese.

PCR is a rapid and extremely sensitive procedure, which is a very good tool for the detection of enterotoxin genes in clinical isolates of $S$. aureus. It can be used for specifying the staphylococcal infection of the mammary gland and to speed up the diagnosis of the hazardous staphylococcal strains.

\section{Detekcia enterotoxínových génov Staphylococcus aureus pomocou PCR}

Cielom predloženej práce bolo stanovit prítomnost̉ génov pre stafylokokové enterotoxíny v skupine 32 izolátov Staphylococcus aureus izolovaných zo 72 vzoriek (surové mlieko oviec, kráv a kôz) odobratých zo subklinických a klinický chorých oviec, kráv a kôz pochádzajúcich z rôznych polnohospodárskych fariem východného Slovenská a tiež z 12 vzoriek ovčieho syra. 15 z 32 izolátov S.aureus malo gény pre enterotoxín C (SEC): 12 zo surového mlieka oviec, po jednom zo surového mlieka kôz, kravy a z ovčieho syra. 15 z 32 izolátov malo gény pre enterotoxín D (SED): 12 zo surového mlieka oviec a 2 zo surového kravského mlieka a 1 z ovčieho syra. 2 z 32 izolátov mali gény pre enterotoxin A (SEA) a B (SEB): jeden izolat zo surového ovčieho mlieka pozitívny pre SEA a druhý izolát $\mathrm{z}$ ovčieho syra pozitívny pre SEB.

\section{References}

BURDOVÁ, O, DUDRIKOVÁ, E, GA·INCOVÁ, E, PLEVA, J 1994: Determination of hylococcal enterotoxins in milk and milk products by three methods. Archivum Veterinarium Polonicum 34: 69-74

GOULOUMES, C, BES, M, RENAND, F, LINA, B, REVERDY, M. E, BRUN, Y, FLEURETTE, J 1996: Phenotypic and genotypic (pulsed-field gel electrophoresis) characteristics of enterotoxin A-producing S. aureus strains. Res Microbiol 147: 263-271

HALPIN-DOHNÁLEK, MI, MARTH, EH 1989: Staphylococcus aureus: Production of extracellular compounds and behaviour in foods - a review. J Food Prot 25: 267-282

HOLECKOVA, B, HOLODA, E, FOTTA M, KALINACOVA, V, GONDOL, J, GROLMUS, J 2002: Occurrence of Enterotoxigenic Staphylococcus aureus in Food. Ann Agric Environ Med 9: 179-182

SAMBROOK J, FRITSCH EF, MANIATIS T 1989: Molecular cloning. A laboratory manual. Cold Spring Harbor Laboratory Press. B.23 p.

SHARMA, N. K., REES, C. E. D., DOOD, C. E. R. 2000: Development of a single-reaction multiplex PCR toxintyping assay for Staphylococcus aureus strains. Appl Envir Microbiol, pp. 1347-1353

STEPHAN, R., DURA, U., UNTERMANN, F. 1999: Resistance situation and enterotoxin production capacity of Staphylococcus aureus strains from bovine mastitis milk samples. Schweiz Arch Tierheilkd 141: 287-290

STRACHAN, NJ, JOHN, PG, MILLAR, IG 1997: Application of a rapid automated immunosensor for the detection of S. aureus enterotoxin B in cream. Int J Food Microbiol 35: 293-297

TORNADIJO, ME, FRESNO, JM, CARBALLO, J, SARIMIENTO, MR 1996: Population levels, species and characteristics of Micrococcaceae during the manufacturing and preparing of Armada-Sobado hard goat's milk cheese. J Food Prot 1200 p.

TSEN, HY, CHEN, TR 1992: Use of polymerase chain reaction for specific detection of type A, D and E enterotoxigenic Staphylococcus aureus in foods. Appl Microbiol Biotechnol 37: 685-690 
Plate XV

Tkáčiková L. et al.: Detection of the Genes...pp. 627-630

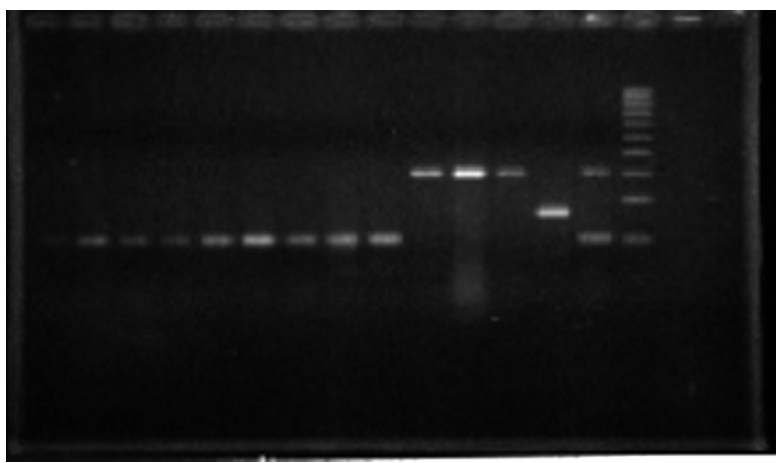

Fig. 1. Gel analysis of PCR-amplified toxin gene sequences. The individual toxin gene products were characterized by comparing with standard molecular size marker. Lane 1-9, SEC (102 bp); lane 10-12, SED (306 bp); lane 13, SEB (165 bp); lane 14, SEC and SED (102 bp and 306 bp). Lane 15, 100 bp DNA ladder. 